\title{
Does the height to entrepreneurship nexus have two stages? New evidence from 27 nations
}

\author{
Nazim Habibov ${ }^{1}$ (D) $\cdot$ Alena Auchynnikava ${ }^{1} \cdot$ Rong Luo $^{2}$ \\ Received: 21 April 2020 / Accepted: 28 February 2021 / Published online: 28 April 2021 \\ (C) The Author(s) 2021
}

\begin{abstract}
We examine the association between height and entrepreneurship in 27 nations, finding that the relationship between height and entrepreneurship can be considered to be a two-stage process. During the first stage, individuals make the decision of whether or not to try to set up their own business. At this stage, the effect of height is stronger: each 10-cm increase in height is associated with an approximately 1.4 percentage point increase in the probability of having tried to set up a business. During the second stage, after a positive decision to embark upon entrepreneurship has already been taken, people may find success in setting up their business. At this stage, although taller individuals are still more likely to experience success than their shorter counterparts, the effect of height becomes much weaker. Each $10-\mathrm{cm}$ increase in height is associated with an approximately 0.4 percentage point increase in the probability of having tried to set up a business without success, and an approximately 0.4 percentage point increase in the likelihood of having set up a business in which the respondent is no longer involved, or that is no longer operational. Finally, each $10-\mathrm{cm}$ increase in height is associated with an approximately 1 percentage point increase in the probability of remaining an entrepreneur. At the same time, we found that the effect of height is stronger in magnitude than the effects of gender, health and university education. This finding is remarkable insofar as gender, health and university education are usually considered to be the main determinants of entrepreneurship.
\end{abstract}

Keywords Entrepreneurship $\cdot$ Self-employment $\cdot$ Height $\cdot$ Eastern Europe $\cdot$ Central Asia $\cdot$ Caucasus

\section{Introduction}

Understanding the effect of an individual's height on the likelihood of being involved in entrepreneurship has recently become an important aspect of research on the determinants of entrepreneurship in both developed and developing countries (Case \& Paxson, 2008; Vogl, 2014; Bargain \& Zeidan, 2017; LaFave \& Thomas, 2017). The existing literature suggests some

Nazim Habibov

nnh@uwindsor.ca

Alena Auchynnikava

auchynn@uwindsor.ca

Rong Luo

luo18@uwindsor.ca

1 School of Social Work, University of Windsor, 167 Ferry Street, Windsor, ON N9A 0C5, Canada

2 The Mathematics and Statistics Department, University of Windsor, 401 Sunset Avenue, Windsor N9A 0C5, Canada explanations regarding why increased height could have a positive influence on being involved in entrepreneurship. For example, the occupational choice theory puts forth that if the outcome (such as earnings, social status and work satisfaction) gained from entrepreneurship is greater than that which is gained from wage employment, then logically, people would choose to embark upon entrepreneurship (Parker, 2009). The talent and abilities of the potential entrepreneur are thus crucial among the conditions that could determine their success (Rietveld et al., 2015). In general, the compensation for abilities is higher in entrepreneurship than in wage work, and because of this, more capable individuals are more likely to achieve high socio-economic status through entrepreneurship than through wage employment (Parker \& Van Praag, 2010). Furthermore, height is a significant precursor of social skills and intelligence, which are required for many types of entrepreneurial occupations such as accounting, law and medicine (Bargain \& Zeidan, 2017; Case \& Paxson, 2008a). As such, more capable individuals have a higher likelihood of enjoying greater levels of autonomy such as making their own decisions regarding tasks and working hours, factors that are more predictably associated with entrepreneurship than 
with wage employment (Benz \& Frey, 2008; Patzelt \& Shepherd, 2011). Moreover, height is positively associated with the emergence of leadership and leadership effectiveness, which are both qualities that are necessary for running one's own business (Lindqvist, 2012; Stulp et al., 2013, 2015). Height is also associated with a higher level of physical power and strength, both of which are required for many types of entrepreneurship, for instance, within the field of agriculture (Sohn, 2015; Thomas $\&$ Strauss, 1997). In addition, the taste-based discrimination theory postulates that customers may consciously favour taller individuals and discriminate against shorter individuals simply because they have a taste for attractive individuals (Becker, 1971; Cinnirella \& Winter, 2009; Mavisakalyan, 2018). For example, taller individuals are judged to be more persuasive and capable (Hensley, 1993; Young \& French, 1996; Zebrowitz, 1994). Finally, the statistical theory of discrimination suggests that employers and customers sometimes deliberately discriminate against shorter workers because they do not have appropriate knowledge about the productivity of employees and so "statistically discriminate" against shorter employees because of apparent physical characteristics such as height (Hübler, 2009; Magnusson et al., 2006).

\section{Literature review}

In spite of several plausible theoretical explanations, the results of empirical studies are far from conclusive, and the generalizability of their findings is fairly low since most of the existing studies have focused on a single country developed country or on a subsection of a country's population (e.g. a specific island or urban population of the country only). As such, focusing on Germany, Rietveld et al. (2015) reported that height is positively associated with the likelihood of being self-employed. In contrast, through their analysis of a sample of developed European countries, Cinnirella and Winter (2009) did not find any association between height and involvement in entrepreneurship. LaFave and Thomas (2017) also did not report any effect of height on entrepreneurship in rural Central Java, Indonesia. In contrast, Djankov et al. (2006) focused on the determinants of entrepreneurship in Brazil, China and Russia and found that height did positively influence the probability of being an entrepreneur in Brazil but that the effects were not significant in China and Russia. Finally, Vogl (2014) reported that height is negatively associated with the likelihood of being self-employed in Mexico.

In light of the above-discussed evidence, the present study is the first attempt to empirically investigate the relationship between height and entrepreneurship across a diverse sample of 27 post-communist countries in Eastern Europe, Central Asia and the Caucasus. Consequently, our study makes two unique contributions. First, because of the multi-country coverage that the survey employed, this study offers a rigorous test with respect to the universality of the relationship between height and participation in entrepreneurship across a range of socio-economic contexts. Second, because of its concentration on postcommunist countries, we are able to study the effects of height in a setting that has not been previously studied. On the one hand, for many years during the communist era, entrepreneurship was strongly discouraged (Ageev et al., 1995; Gurov \& Carstensen, 1983; Habibov, Auchynnikava, et al., 2020a; Rietveld et al., 2015; Welter, 2012). On the other hand, the entrepreneurship that exists in post-communist countries today is characterized by weak institutional accommodations and economic and political instability (Aidis et al., 2008). Furthermore, in post-communist countries, entrepreneurship has become a prestigious occupation that is associated with higher levels of income and social status (Habibov, Afandi, \& Cheung, 2017a; Habibov, Cheung, \& Auchynnikava, 2017b). At the same time, it is important to gain a greater understanding of entrepreneurship in transitional countries. This includes developing a more thorough understanding of the effects of height since, in contrast to state-owned or privatized companies, new businesses need to be more market-oriented and efficient in terms of management in order to be competitive under the new conditions (McMillan \& Christopher, 2002). Entrepreneurship in the private sector provides a vital buffer against economic shocks during transition since it generates employment and alternative sources of income (George et al., 2012).

Examining the association between height and likelihood of involvement in entrepreneurship, this study attempts to address the following research questions:

1) What is the association between the height of individuals and the probability of never having tried to set up one's own business?

2) What is the association between the height of individuals and the probability of having tried to set up one's own business even if did not succeed?

3) What is the association between the height of individuals and the probability of having set up their own business that is currently operational?

4) What is the association between the height of individuals and the probability of having set up own business even if it is no longer operational?

Answering these four questions allows us to examine a whole range of possible situations related to involvement in entrepreneurship.

\section{Data, measurement and methodology}

\section{Data}

The data set used in this study is the 2016 Life-In-Transition Survey (LITS), a cross-sectional survey that was jointly 
conducted in 27 post-communist countries by the European Bank for Reconstruction and Development and the World Bank (EBRD, 2016). Countries included in this survey are Albania, Armenia, Azerbaijan, Belarus, Bosnia, Bulgaria, Croatia, Czech Republic, Estonia, Georgia, Hungary, Kazakhstan, Kyrgyzstan, Latvia, Lithuania, Macedonia, Moldova, Mongolia, Poland, Romania, Russia, Serbia, Slovakia, Slovenia, Tajikistan, Ukraine and Uzbekistan.

LITS utilizes a multistage sampling design. A list of primary selection units (PSU), the so-called sampling frame, is obtained from national statistical authorities in each of the participating countries in the first stage of sampling. This list is based on the most recent national census. The PSUs represent communities or census tracts with clearly defined borders. Following that, the probability proportional to size technique is applied to select the PSU from the sampling frame, in the second stage of sampling. This technique gives more populated PSUs a greater probability to be selected as compared with less populated PSUs. Using this technique, between 50 to 70 PSU are selected per country. The exact number of PSUs per country depends on the size of the country, size of population and density of population. Next, the random walk technique is employed to select households within each PSU for an interview in the third stage of sampling. In the last stage of the sampling, the list of all household members with their birthdates is created. The selection of household members for the interview is conducted by employing the last birthday technique. In this way, approximately 1500 respondents were interviewed in each of the 27 countries by trained interviewers.

Special attention was paid to the questionnaire development to ensure direct cross-country comparability. At the first stage of the questionnaire development, the EBRD and the World Bank cooperated to design the initial version of the master questionnaire in English. In the second stage, the team of experienced professional interpreters translated the master questionnaire into local languages. In the third stage, the translated questionnaire was sent to each country. In each country, local interviews went through the translated version to verify the questionnaire. The local interviews in each country provided feedback about the quality of the questionnaire which was referred to the team of professional interpreters. In the next stage, the team of professional interpreters went through the translated national versions to incorporate the feedback from the local teams. In the final stage, the revised versions were piloted to further adjust the questionnaire. The feedback from pilot testing was also incorporated into the final version of the questionnaire. In addition, given that Russian was widely spoken in the countries of the former Soviet Union, using the Russian version of the questionnaire was provided as an option for the respondents. Detailed descriptions of the sampling frame and methodology of this survey can be found in Habibov and
Cheung (2017) and Habibov, Afandi, and Cheung (2017a); Habibov, Cheung, and Auchynnikava (2017b).

The LITS contains data about height, socio-demographic status and involvement in entrepreneurship. As such, it is highly appropriate for use in our study on the relationship between height and entrepreneurship. Furthermore, it also well suited for our aim of full comparability since the information was gathered across a diverse sample in these countries.

\section{Outcome variables}

The LITS asked about involvement in entrepreneurship by posing the following question (Q701), "Have you ever tried to set up a business?" The range of answers varied from 1 to 4 , where $1=$ no; $2=$ yes, I tried to set up a business but did not succeed in setting it up; $3=$ yes, I set up a business in the past but I am no longer involved in it or it is no longer operational; $4=$ yes, I have set up my current business that is currently operational. These four possible answers reflect a whole range of possible situations related to engagement in entrepreneurship. Consequently, we use these four binomial variables as the outcome variables in our study.

\section{Predictor}

The main predictor of interest in our study is height in centimetres. Height in the LITS is mainly self-reported. However, in a single PSU per country, height was measured physically using a stadiometer. The correlation between selfreported and actual height is found to be very strong (Person's $r=0.953, p<0.001)$, suggesting that self-reported height very accurately represents actual height.

\section{Covariates}

We control for a number of factors that are commonly used in studying the determinants of entrepreneurship including age, age squared, weight, education, marital status, health status, number of children, size of social network (number of community organizations in which respondent has actively participated) and country dummies to capture country fixed effects (Grilo \& Thurik, 2005; Habibov, Afandi, \& Cheung, 2017a; Habibov, Cheung, \& Auchynnikava, 2017b; Mussurov \& Arabsheibani, 2015; Parker, 2009). The descriptive statistics and definitions for all variables, along with the source of data, are presented in Table 1 .

\section{Methodology}

Since we have four possible answers to the question "Have you ever tried to set up a business?" (i.e. Set up my current business, Set up a business in the past but no longer involved in it or it is no longer operational, Tried to set up a business 
Table 1 Descriptive statistics

\begin{tabular}{|c|c|c|c|c|c|}
\hline Variable & Mean & Std. Dev. & Min & Max & Source \\
\hline \multicolumn{6}{|l|}{ Predictor } \\
\hline Height $(\mathrm{cm})$ & 169.241 & 9.2 & 110 & 218 & LITS \\
\hline \multicolumn{6}{|l|}{ Outcome variables } \\
\hline Set up my current business & 0.056 & & 0 & 1 & LITS \\
\hline $\begin{array}{l}\text { Set up a business in the past but no longer involved in it } \\
\text { or it is no longer operational }\end{array}$ & 0.033 & & 0 & 1 & LITS \\
\hline Tried to set up a business and did not succeed. & 0.037 & & 0 & 1 & LITS \\
\hline Never tried to set up a business & 0.875 & & 0 & 1 & LITS \\
\hline \multicolumn{6}{|l|}{ Covariates } \\
\hline Women $($ women $=1)$ & 0.572 & & 0 & 1 & LITS \\
\hline Weight (kg) & 74.406 & 14.892 & 35 & 197 & LITS \\
\hline Age (in years continuous) & 48.759 & 17.452 & 18 & 95 & LITS \\
\hline Age squared (in years continuous) & 2681.96 & 1779.76 & 324 & 9025 & LITS \\
\hline Married (married $=1$ ) & 0.581 & & 0 & 1 & LITS \\
\hline High education (bachelor or above $=1$ ) & 0.2 & & 0 & 1 & LITS \\
\hline Poor health (reported bad or very bad health) & 0.139 & & 0 & 1 & LITS \\
\hline Number of children (continuous) & 0.632 & 1.014 & 0 & 8 & LITS \\
\hline $\begin{array}{l}\text { Size of social network (continuous, number of community } \\
\text { organizations such as sports clubs or churches in which } \\
\text { respondent actively participated). }\end{array}$ & 0.198 & 0.668 & 0 & 10 & LITS \\
\hline \multicolumn{6}{|l|}{ Robust analysis } \\
\hline Height (SD) & 3.503 & 1.016 & 1 & 6 & LITS \\
\hline $\begin{array}{l}\text { GDP per capita adjusted for purchasing power parity } \\
\text { (PPP) for (GDP for 2016) }\end{array}$ & $18,615.1$ & 9518.68 & 2985.1 & $35,139.6$ & $\begin{array}{l}\text { World Development Indicators } \\
\text { (Work Bank, n.d.) }\end{array}$ \\
\hline $\begin{array}{l}\text { Lagged GDP per capita adjusted for purchasing power } \\
\text { parity (PPP) (GDP for 2015) }\end{array}$ & $18,080.3$ & 9286.34 & 2817.3 & $34,048.2$ & $\begin{array}{l}\text { World Development Indicators } \\
\text { (Work Bank }\end{array}$ \\
\hline $\begin{array}{l}\text { Annual GDP growth in percentage points } \\
\text { for } 2016\end{array}$ & 2.32907 & 2.29953 & -4.2 & 5.9 & $\begin{array}{l}\text { World Development Indicators } \\
\text { (Work Bank }\end{array}$ \\
\hline $\begin{array}{l}\text { Lagged GDP growth in percentage points } \\
\text { for } 2015\end{array}$ & 1.89502 & 3.17634 & -9.4 & 6.1 & $\begin{array}{l}\text { World Development Indicators } \\
\text { (Work Bank }\end{array}$ \\
\hline Economic Freedom Index & 7.14882 & 0.50576 & 5.98 & 8.02 & $\begin{array}{l}\text { Economic freedom of the world } \\
\text { (Fraser Institute, n.d.) }\end{array}$ \\
\hline
\end{tabular}

and did not succeed and Never tried to set up a business), we estimate four binomial logit regressions models. It should be highlighted that in the initial stages of our analysis, we attempted to estimate a multinomial logit model, but such a model failed Hausman-McFadeen and Small-Hsaio tests of independence of irrelevant alternatives. Hence, estimating binomial logit regression for each outcome separately is the only viable way to proceed (Long \& Freese, 2014).

Consequently, in each model, we regress each outcome variable on the main predictor of interest, height, while controlling for a set of covariates including country dummies. More formally, we estimate the following model:

$\ln \left(\frac{P}{1-P}\right)=$ predictor variable $\beta+$ covariates $\gamma_{1}$

$$
+ \text { country dummies } \gamma_{2}+\text { constant, }
$$

where $p$ is the probability that the outcome variable equals to 1 , predictor variable is the height of individuals and covariates are age, age squared, weight, education, marital status, health status, number of children, size of social network (number of community organizations in which respondent has actively participated) and country dummies. The outputs of the regression include regression coefficients, standard errors which are robust for clustering at PSU level and statistical significance at conventional levels $(*<0.05 ; * *<0.01 ; * * *<0.001)$.

However, since regression coefficients do not have straightforward interpretation in non-linear models with categorical outcomes, we transformed them to marginal effect to facilitate interpretation (Long \& Freese, 2014). After transformation, the marginal effects $(\alpha)$ are interpreted as a percentage point change in probability of outcome variable to have a value of 1 (i.e. Never tried to set up a business) for a change in predictor height, holding all covariates constant. 
In addition, we estimate and report standardized regression coefficients. Note that predictor and covariates are measured in different units of measurement, for instance, height, education and country dummies. Analysing standardized regression coefficients allows us to directly compare the effect of predictor and covariates on the outcome variables (Long \& Freese, 2014).

\section{Descriptive results}

The distribution of answers to the questions about involvement in entrepreneurship is reported in Fig. 1. As shown, the overwhelming majority of respondents, approximately $87 \%$, had never tried to set up their own business. Approximately $4 \%$ of respondents tried to open their own business but did not succeed in setting it up. At the same time, approximately $3 \%$ of respondents had set up a business in the past but were either no longer involved in it or it was no longer operational. Finally, about $6 \%$ of respondents had set up their current business, and this business was currently operational.

\section{Multivariate results}

The results of multivariate analysis are reported in Table 2. As shown in model 1 , each 10 -cm increase in height is associated with an approximately 1.4 percentage points reduction in the probability of having never tried to set up a business $(\alpha=-$ $0.0014 * * *)$. Please note that Table 1 reports the absolute value of marginal effect $(\alpha)$ that is -0.0014 . We multiply this value by 100 to arrive at percentage points. Since changes in outcome variable per $\mathrm{cm}$ change are negligible, we further multiply the value of marginal effect to 10 to be able to discuss the changes in outcome variable as a result of changes in height in the increment of $10 \mathrm{~cm}$.

Conversely, model 2 indicates that each 10-cm increase in height is associated with an approximately 0.4 percentage points increase in the probability of having tried to set up a business but not having succeeded in doing so $(\alpha=$ $0.0004 * *)$. Similarly, model 3 suggests that each $10-\mathrm{cm}$ increase in height is associated with an about 0.4 percentage points increase in the likelihood of having set up a business in which the respondent is no longer involved or which is no longer operational ( $\alpha=0.0004 * *)$. Lastly, model 4 indicates that each $10-\mathrm{cm}$ increase in height is associated with an approximately 1 percentage point increase in the probability of having a current business $\left(\alpha=0.0007^{* *}\right)$.

To compare the strengths of predictors within the model, we computed standardized coefficients. Thus, in model 1, which focused on the probability of having tried to open one's own business, the effect of height $(\beta=0.8812)$ is stronger in magnitude than the effect of university education $(\beta=0.4047)$, and close to the effect of the size of social network ( $\beta$ $=0.9166$ ). At the same time, the effect of height in this model is lower in magnitude, although not by very much, than the effects of poor health $(\beta=1.0584)$ and gender $(\beta=1.2234)$. Equally, in model 4, which focused on the likelihood of currently having one's own business, the effect of height ( $\beta=$ $1.1247)$ is stronger in magnitude than the effects of gender $(\beta=0.8311)$, university education $(\beta=0.4047)$, poor health $(\beta=0.8289)$ and very close to the effect of the size of social network ( $\beta=1.0992)$. The results of standardized coefficients are similar in models 2 and 3 so we do not discuss them in detail to conserve valuable journal space.

\section{Robustness analysis}

We test the robustness of our main results to (1) a different specification of the predictor, height and (2) a different set of covariates. First, we test the robustness of our main results to a different specification of the predictor, height. In our main model, we used height in centimetres. Consequently, our results could be biased if average height substantially differs in

Fig. 1 Involvement in entrepreneurship

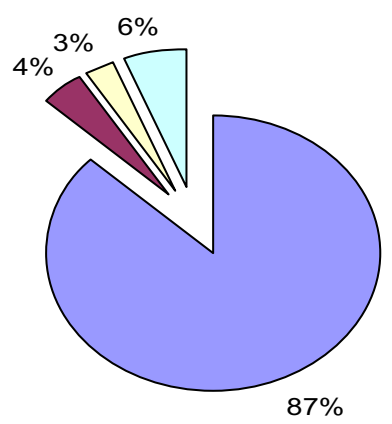
$\square$ I have never tried to set up my own business
- I have tried to open my own business, but did not succeed in setting it up
$\square$ I have set up my own business in the past but no longer involved in it or it is no longer operationa
$\square$ I have set up my current business and this business is currently operational




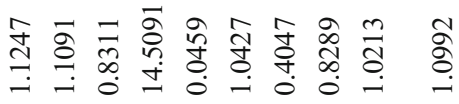

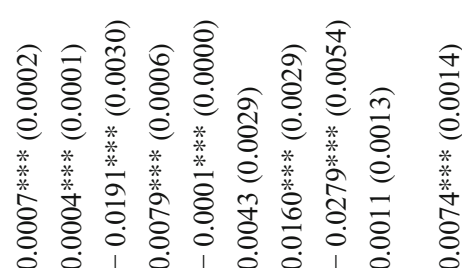

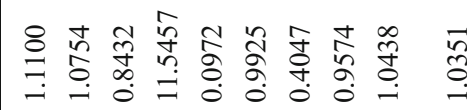

을

च

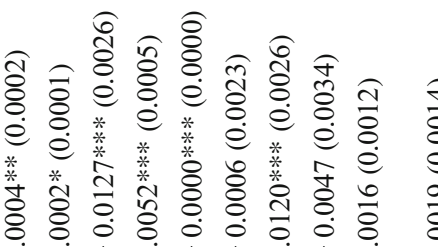

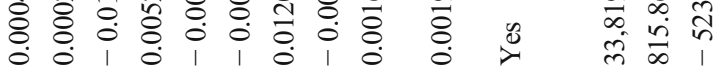

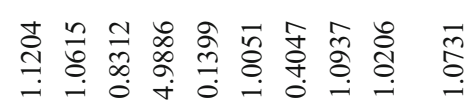

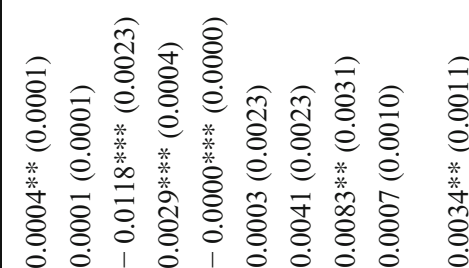

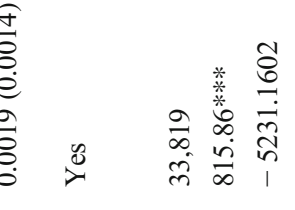

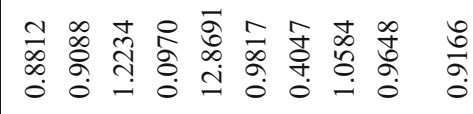

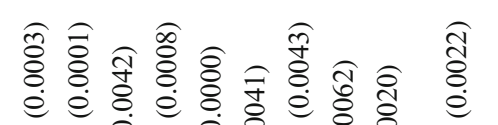

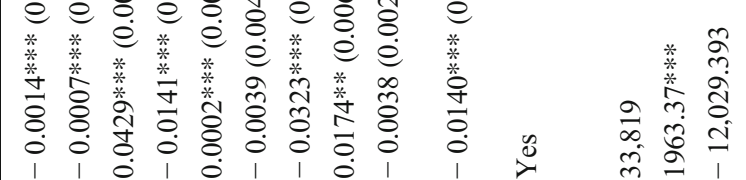

के

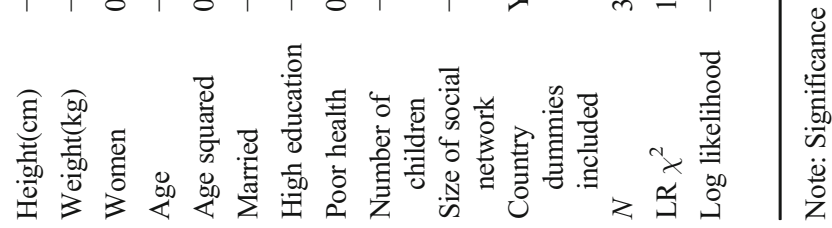


the samples of analyzed countries (Rietveld et al., 2015). In order to take possible across-country differences of height into account, we transformed height into standard deviations for each country (Sohn, 2015). Then, we re-estimated models 1 to 4 using height in standard deviations.

The results are reported in Table 3. As observed in model 5, a one percentage point increase in the standard deviation of height is associated with an approximately 1 percentage points reduction in the probability of having never tried to set up a business $\left(\alpha=-0.0082^{* * *}\right)$. In contrast, the effect of height in models 6 and 7 becomes non-significant $(\alpha=0.0020$ and $\alpha=$ 0.0022). Finally, model 8 demonstrates that a one percentage point increase in the standard deviation of height is associated with an approximately 0.41 percentage point increase in the probability of currently having one's own business ( $\alpha=-$ $\left.0.0041^{* *}\right)$.

Next, we test the robustness of our main results to a different set of covariates. We drop country dummies and instead use a number of country-level covariates that may be associated with entry into entrepreneurship such as GDP per capita adjusted for purchasing power parity (PPP), lagged GDP per capita adjusted for purchasing power parity (PPP), annual GDP growth in percentage, lagged GDP per capita in percentage and the Economic Freedom Index. Then, we re-estimate models 1 to 4 using these covariates instead of country dummies. Evidently, these variables are correlated with each other. For instance, GDP is correlated with the Economic Freedom Index. Therefore, in order to avoid spurious correlation, we included the country-level covariates into the regression models one at a time. The results of re-estimation are reported in panels A to $\mathrm{E}$ of Table 4.
Let us begin with panel A that tests the inclusion of GDP per capita as a covariate instead of country dummies. As demonstrated, an increase in height is still associated with a lower likelihood of not trying to open one's own business ( $\alpha=-$ $0.0005 *$ ). Equally, an increase in height is still associated with an increase in the likelihood of currently having one's own business $\left(\alpha=0.0005^{* *}\right)$.

Let us continue with panel B that tests the inclusion of lagged GDP per capita as a covariate instead of country dummies. As observed, an increase in height is associated with a lower likelihood of not trying to open one's own business $\left(\alpha=-0.0005^{*}\right)$. Likewise, an increase in height is associated with an increase in the likelihood of currently having one's own business ( $\left.\alpha=0.0005^{* *}\right)$.

Let us now move to panel $\mathrm{C}$ which tests the inclusion of annual GDP growth as a covariate instead of country dummies. Let us continue with panel B that tests the inclusion of lagged GDP per capita as a covariate instead of country dummies. As shown, an increase in height remains to be associated with a lower likelihood of not trying to open one's own business $\left(\alpha=-0.0005^{*}\right)$. Likewise, an increase in height remains to be associated with an increase in the likelihood of currently having one's own business ( $\alpha=0.0004 * *)$.

Next, panel D tests the inclusion of lagged annual GDP growth as a covariate. An increase in height remained to be positively associated with an increase in the likelihood of currently having one's own business ( $\alpha=0.0004 *$ ).

Finally, in panel E, we test the inclusion of the Economic Freedom Index as a covariate. The inclusion of this index instead of country dummies also does not change results. An increase in height is associated with a lower likelihood of not

Table 3 Probability of being involved in entrepreneurship (binomial logit)

\begin{tabular}{|c|c|c|c|c|}
\hline & $\begin{array}{l}\text { Model } 5 \\
\text { Marginal effects and } \\
\text { (robust standard errors) }\end{array}$ & $\begin{array}{l}\text { Model } 6 \\
\text { Marginal effects and } \\
\text { (robust standard errors) }\end{array}$ & $\begin{array}{l}\text { Model } 7 \\
\text { Marginal effects and } \\
\text { (robust standard errors) }\end{array}$ & $\begin{array}{l}\text { Model } 8 \\
\text { Marginal effects and } \\
\text { (robust standard errors) }\end{array}$ \\
\hline Height (SD) & $-0.0082 * * *(0.0019)$ & $0.0020(0.0011)$ & $0.0022(0.0012)$ & $0.0041 * *(0.0014)$ \\
\hline Weight(kg) & $-0.0008 * * *(0.0001)$ & $0.0002 *(0.0001)$ & $0.0002 * *(0.0001)$ & $0.0004 * * *(0.0001)$ \\
\hline Women & $0.0556^{* * *}(0.0039)$ & $-0.0150 * * *(0.0021)$ & $-0.0166^{* * *}(0.0023)$ & $-0.0248 * * *(0.0028)$ \\
\hline Age & $-0.0141 * * *(0.0008)$ & $0.0029 * * *(0.0004)$ & $0.0052 * * *(0.0005)$ & $0.0078 * * *(0.0006)$ \\
\hline Age squared & $0.0002 * * *(0.0000)$ & $-0.0000 * * *(0.0000)$ & $-0.0000 * * *(0.0000)$ & $-0.0001 * * *(0.0000)$ \\
\hline Married & $-0.0040(0.0041)$ & $0.0003(0.0023)$ & $-0.0006(0.0023)$ & $0.0044(0.0029)$ \\
\hline High education & $-0.0325 * * *(0.0043)$ & $0.0042(0.0023)$ & $0.0121 * * *(0.0026)$ & $0.0160 * * *(0.0029)$ \\
\hline Poor health & $0.0178 * *(0.0062)$ & $0.0081 * *(0.0031)$ & $-0.0048(0.0034)$ & $-0.0280 * * *(0.0054)$ \\
\hline Number of children & $-0.0038(0.0020)$ & $0.0006(0.0010)$ & $0.0016(0.0012)$ & $0.0011(0.0013)$ \\
\hline Size of social network & $-0.0140 * * *(0.0022)$ & $0.0034 * *(0.0011)$ & $0.0020(0.0014)$ & $0.0074 * * *(0.0014)$ \\
\hline Country dummies included & Yes & Yes & Yes & Yes \\
\hline$N$ & 33,819 & 33,819 & 33,819 & 33,819 \\
\hline $\operatorname{LR} \chi^{2}$ & $1951.00 * * *$ & $621.96^{* * *}$ & $812.51 * * *$ & $1018.46^{* * *}$ \\
\hline Log likelihood & $-12,035.575$ & -4650.6688 & -5232.8341 & -6789.8502 \\
\hline
\end{tabular}

Note: Significance $*<0.05 ; * *<0.01 ; * * *<0.001$ 
Table 4 Robustness analysis of the probability of being involved in entrepreneurship (binomial logit)

Never tried to set up a Tried to set up a business Set up a business in the business

and did not succeed.

Marginal effects and Marginal effects and

(robust standard errors) (robust standard errors) past but no longer involved in it or it is no longer operational Marginal effects and (robust standard errors)
Set up my current business

Marginal effects and (robust standard errors)
Panel A: GDP per capita

Height $(\mathrm{cm})$

Weight $(\mathrm{kg})$

Women

Age

Age squared

Married

High education

Poor health

Number of children

Size of social network

GDP per capita adjusted for purchasing power parity (PPP)

$N$

LR $\chi^{2}$

Log likelihood

Panel B: lagged GDP per capita

Height $(\mathrm{cm})$
Weight $(\mathrm{kg})$
Women
Age
Age squared
Married
High education
Poor health
Number of children
Size of social network
Lagged GDP per capita adjusted
for purchasing power parity (PPP)
$N$

LR $\chi^{2}$

Log likelihood
$-0.0000(0.0001)$

$0.0002(0.0001)$

$-0.0144 * * *(0.0023)$

$0.0030 * * *(0.0004)$

$-0.0000 * * *(0.0000)$

$0.0004(0.0023)$

$0.0058 *(0.0023)$

$0.0084 * *(0.0031)$

$0.0022 *(0.0010)$

$-0.0092 * * *(0.0019)$

$-0.0161 * * *(0.0022)$

$0.0000(0.0000)$

33,819

$1208.20 * * *$

$-12,406.977$

$-0.0005 *(0.0003)$
$-0.0008^{* * *}(0.0001)$
$0.0505 * * *(0.0043)$
$-0.0143 * * *(0.0008)$
$0.0002 * * *(0.0000)$
$0.0000(0.0041)$
$-0.0344 * * *(0.0042)$
$0.0194 * *(0.0063)$
$-0.0092 * * *(0.0019)$
$-0.0161 * * *(0.0022)$
$0.0000(0.0000)$
33,819
$1208.20 * * *$
$-12,406.977$

$-0.0000(0.0001)$

$0.0002(0.0001)$

$-0.0144 * * *(0.0023)$

$0.0030^{* * * *}(0.0004)$

$-0.0000 * * *(0.0000)$

$0.0004(0.0023)$

$0.0059 * *(0.0023)$

$0.0085 * *(0.0031)$

$0.0023 *(0.0010)$

$0.0037 * *(0.0011)$

$-0.0000 * * *(0.0000)$

33,819

$336.51 * * *$

$-4793.3944$
Panel C: annual GDP growth in percentage

Height $(\mathrm{cm})$
Weight $(\mathrm{kg})$
Women
Age
Age squared
Married
High education
Poor health
Number of children
Size of social network
Annual GDP growth in
percentage points

$-0.0001(0.0001)$

$0.0001(0.0001)$

$-0.0153 * * *(0.0023)$

$0.0029 * * *(0.0004)$

$-0.0000 * * *(0.0000)$

$0.0018(0.0022)$

$0.0059 *(0.0023)$

$0.0090 * *(0.0031)$

$0.0036 * * *(0.0010)$

$0.0036^{* *}(0.0011)$

$-0.0022 * * *(0.0004)$

$0.0000(0.0002)$
$0.0003 * *(0.0001)$
$-0.0157 * * *(0.0026)$
$0.0052 * * *(0.0005)$
$-0.0000^{* * *}(0.0000)$
$-0.0029(0.0023)$
$0.0128^{* * *}(0.0025)$
$-0.0030(0.0034)$
$0.0035 * *(0.0012)$
$0.0032 *(0.0013)$
$0.0000^{* * *}(0.0000)$
33,819
$343.78 * * *$
-5467.1974

$0.0000(0.0002)$

$0.0003 * *(0.0001)$

$-0.0157 * * *(0.0026)$

$0.0052 * * *(0.0005)$

$-0.0000 * * *(0.0000)$

$-0.0029(0.0023)$

$0.0127 * * *(0.0025)$

$-0.0031(0.0034)$

$0.0035 * *(0.0012)$

$0.0032 *(0.0013)$

$0.0000 * * *(0.0000)$

33,819

$343.88 * * *$

$-5467.1498$

$0.0001(0.0002)$

$0.0003 * * *(0.0001)$

$-0.0144 * * *(0.0026)$

$0.0052 * * *(0.0005)$

$-0.0000 * * *(0.0000)$

$-0.0055 *(0.0023)$

$0.0110 * * *(0.0025)$

$-0.0045(0.0034)$

$0.0021(0.0012)$

$0.0034 * *(0.0013)$

$-0.0013^{* *}(0.0005)$
$0.0005 * *(0.0002)$

$0.0003 * * *(0.0001)$

$-0.0209 * * *(0.0030)$

$0.0079 * * *(0.0006)$

$-0.0001 * * *(0.0000)$

$0.0028(0.0029)$

$0.0156^{* * * *}(0.0028)$

$-0.0319 * * *(0.0054)$

$0.0027 *(0.0013)$

$0.0080 * * *(0.0014)$

$-0.0000(0.0000)$

33,819

$768.02 * * *$

$-6915.0726$

$0.0005 * *(0.0002)$

$0.0003 * * *(0.0001)$

$-0.0209^{* * *}(0.0030)$

$0.0079 * * *(0.0006)$

$-0.0001 * * *(0.0000)$

0.0027 (0.0029)

$0.0156^{* * * *}(0.0028)$

$-0.0319^{* * * *}(0.0054)$

$0.0027 *(0.0013)$

$0.0080 * * *(0.0014)$

-0.0000 (0.0000)

33,819

$768.24 * * *$

$-6915.0726$

$0.0004 *(0.0002)$

$0.0003 * * *(0.0001)$

$-0.0214 * * *(0.0030)$

$0.0079 * * *(0.0006)$

$-0.0001^{* * *}(0.0000)$

$0.0036(0.0028)$

$0.0165^{* * * *}(0.0028)$

$-0.0313 * * *(0.0054)$

$0.0029 *(0.0013)$

$0.0080 * * *(0.0014)$

$0.0016 * *(0.0006)$ 
Table 4 (continued)

\begin{tabular}{|c|c|c|c|c|}
\hline & $\begin{array}{l}\text { Never tried to set up a } \\
\text { business } \\
\text { Marginal effects and } \\
\text { (robust standard errors) }\end{array}$ & $\begin{array}{l}\text { Tried to set up a business } \\
\text { and did not succeed. } \\
\text { Marginal effects and } \\
\text { (robust standard errors) }\end{array}$ & $\begin{array}{l}\text { Set up a business in the } \\
\text { past but no longer involved } \\
\text { in it or it is no longer operational } \\
\text { Marginal effects and (robust } \\
\text { standard errors) }\end{array}$ & $\begin{array}{l}\text { Marginal effects and } \\
\text { (robust standard errors) }\end{array}$ \\
\hline$N$ & 33,819 & 33,819 & 33,819 & 33,819 \\
\hline $\operatorname{LR} \chi^{2}$ & $1215.63 * * *$ & $322.09 * * *$ & $306.97 * * *$ & $774.25^{* * *}$ \\
\hline Log likelihood & $-12,403.26$ & -4800.6012 & -5485.6027 & -6911.9584 \\
\hline \multicolumn{5}{|c|}{ Panel D: lagged annual GDP growth in percentage } \\
\hline Height (cm) & $-0.0004(0.0003)$ & $-0.0001(0.0001)$ & $0.0001(0.0002)$ & $0.0004 *(0.0002)$ \\
\hline Weight (kg) & $-0.0008^{* * *}(0.0001)$ & $0.0001(0.0001)$ & $0.0003^{* * *}(0.0001)$ & $0.0003 * * *(0.0001)$ \\
\hline Women & $0.0508 * * *(0.0043)$ & $-0.0156^{* * *}(0.0023)$ & $-0.0146^{* * *}(0.0026)$ & $-0.0213 * * *(0.0030)$ \\
\hline Age & $-0.0144 * * *(0.0008)$ & $0.0029 * * *(0.0004)$ & $0.0053 * * *(0.0005)$ & $0.0079 * * *(0.0006)$ \\
\hline Age squared & $0.0002 * * *(0.0000)$ & $-0.0000 * * *(0.0000)$ & $-0.0000^{* * *}(0.0000)$ & $-0.0001 * * *(0.0000)$ \\
\hline Married & $-0.0009(0.0040)$ & $0.0026(0.0022)$ & $-0.0051 *(0.0023)$ & $0.0037(0.0028)$ \\
\hline High education & $-0.0381 * * *(0.0042)$ & $0.0070 * *(0.0023)$ & $0.0134 * * *(0.0025)$ & $0.0176^{* * *}(0.0029)$ \\
\hline Poor health & $0.0178 * *(0.0063)$ & $0.0096^{* *}(0.0031)$ & $-0.0035(0.0034)$ & $-0.0310 * * *(0.0054)$ \\
\hline Number of children & $-0.0088^{* * *}(0.0018)$ & $0.0034 * * *(0.0010)$ & $0.0019(0.0011)$ & $0.0026 *(0.0013)$ \\
\hline Size of social network & $-0.0158^{* * *}(0.0022)$ & $0.0035 * *(0.0011)$ & $0.0033^{*}(0.0013)$ & $0.0079 * * *(0.0014)$ \\
\hline $\begin{array}{l}\text { Lagged annual GDP growth } \\
\text { in percentage points }\end{array}$ & $-0.0037 * * *(0.0006)$ & $0.0002(0.0003)$ & $0.0019 * * *(0.0004)$ & $0.0018^{* * *}(0.0005)$ \\
\hline$N$ & 33,819 & 33,819 & 33,819 & 33,819 \\
\hline $\operatorname{LR} \chi^{2}$ & $1241.82 * * *$ & $294.94 * * *$ & $323.55 * * *$ & $783.47 * * *$ \\
\hline Log likelihood & $-12,390.168$ & -4814.1794 & -5477.312 & -6907.3475 \\
\hline \multicolumn{5}{|c|}{ Panel E: Economic Freedom Index } \\
\hline Height (cm) & $-0.0006^{*}(0.0003)$ & $-0.0001(0.0001)$ & $0.0002(0.0002)$ & $0.0005 * *(0.0002)$ \\
\hline Weight (kg) & $-0.0006^{* * *}(0.0001)$ & $0.0001(0.0001)$ & $0.0002 * *(0.0001)$ & $0.0003 * *(0.0001)$ \\
\hline Women & $0.0508 * * *(0.0043)$ & $-0.0158^{* * *}(0.0024)$ & $-0.0147^{* * *}(0.0026)$ & $-0.0212^{* * * *}(0.0030)$ \\
\hline Age & $-0.0143^{* * *}(0.0008)$ & $0.0029 * * *(0.0004)$ & $0.0052 * * *(0.0005)$ & $0.0079 * * *(0.0006)$ \\
\hline Age squared & $0.0002 * * *(0.0000)$ & $-0.0000 * * *(0.0000)$ & $-0.0000^{* * *}(0.0000)$ & $-0.0001 * * *(0.0000)$ \\
\hline Married & $-0.0048(0.0040)$ & $0.0035(0.0022)$ & $-0.0033(0.0023)$ & $0.0049(0.0028)$ \\
\hline High education & $-0.0352 * * *(0.0042)$ & $0.0070 * *(0.0023)$ & $0.0114 * * *(0.0025)$ & $0.0162 * * *(0.0028)$ \\
\hline Poor health & $0.0200^{* *}(0.0062)$ & $0.0094 * *(0.0031)$ & $-0.0049(0.0034)$ & $-0.0319 * * *(0.0054)$ \\
\hline Number of children & $-0.0098^{* * *}(0.0019)$ & $0.0035^{* * *}(0.0010)$ & $0.0025 *(0.0012)$ & $0.0030 *(0.0013)$ \\
\hline Size of social network & $-0.0159 * * *(0.0022)$ & $0.0035 * *(0.0012)$ & $0.0034 *(0.0013)$ & $0.0080^{* * * *(0.0014)}$ \\
\hline Economic Freedom Index & $-0.0576^{* * *}(0.0038)$ & $0.0108 * * *(0.0021)$ & $0.0298 * * *(0.0024)$ & $0.0181 * * *(0.0026)$ \\
\hline$N$ & 33,819 & 33,819 & 33,819 & 33,819 \\
\hline $\operatorname{LR} \chi^{2}$ & $1447.03 * * *$ & $323.43 * * *$ & $474.14^{* * *}$ & $816.56^{* * *}$ \\
\hline Log likelihood & $-12,287.564$ & -4799.9329 & -5402.0173 & -6890.8011 \\
\hline
\end{tabular}

Note: Significance $*<0.05 ; * *<0.01 ; * * *<0.001$

trying to open one's own business $\left(\alpha=-0.0006^{*}\right)$ and a higher likelihood of currently having one's own business $\left(\alpha=0.0005^{* *}\right)$.

\section{Discussion of results and conclusion}

There are strong theoretical reasons to believe that height has a positive impact on entrepreneurship. However, the results of empirical studies are far from consistent, with some studies confirming a positive effect, while others reporting no effect at all or even a negative effect. In addition, the generalizability of findings is low since most of the extant studies have focused on a single country or subsection of a country's population (e.g. a specific part of the country or only on a specific subgroup of the population). At the same time, the literature stresses that future research should extend to more countries where the status of entrepreneurs differ (Rietveld et al., 2015). 
Against this background, the focus of this study is on the influence of height on the probability of being an entrepreneur in a diverse sample of 27 post-communist countries.

Answering the series of posted research questions about the association between height and involvement in entrepreneurship, we found that height is positively associated with the likelihood of having tried to set up one's own business and the likelihood of having succeeded in setting up one's own business. Height is also positively associated with having set up one's own business that is currently operational. In contrast, height is negatively associated with the likelihood of not having tried to set up one's own business. The strong positive effect of height is stable against a comprehensive set of covariates such as gender, experience, education, health status, number of children and country-level characteristics, which are usually used to determine entry into entrepreneurship. Our results are robust to a different specification of predictor, height and a different set of covariates, as well as a different statistical specification in terms of direction and significance.

This study contributes to the expanding literature on height and entrepreneurship by demonstrating that a consistent height premium exists across a large and diverse sample of 27 post-communist countries of Eastern Europe, Central Asia and the Caucasus. The results of our study convey that overall, the effect of height on entrepreneurship in the emerging postcommunist economies is not fundamentally different from the situation in developed and developing countries such as Germany and Brazil, where height is associated with entrepreneurship (Djakonov et al., 2006; Rietveld et al., 2015). At the same time, we found that the effect of height is stronger in magnitude than the effects of gender, health and university education. This finding is remarkable insofar as gender, health and university education are considered to be the main determinants of entrepreneurship (Habibov, Afandi, \& Cheung, 2017a; Habibov, Cheung, \& Auchynnikava, 2017b).

This study also contributes to the expanding literature on height and entrepreneurship by showing that height has the strongest effect on the probability of becoming an entrepreneur and a much lower effect on the probability of becoming successful as an entrepreneur. Our findings suggest that relatively taller individuals are more likely to try to become entrepreneurs when compared with shorter individuals (1.5 percentage points for each additional $10 \mathrm{~cm}$ in height). Thus, taller workers self-select themselves into entrepreneurship, which can generate higher returns, better working conditions and higher life satisfaction. At the same time, height is also correlated with a higher demand for physical capacity, abilities and human and social capital, as well as prestige and life satisfaction (Habibov, Luo, et al., 2020b; Sohn, 2015; Vogl, 2014).

In comparison, height has a much lower effect on the next steps in entrepreneurship, namely, $(i)$ trying to set up a business but not succeeding in setting it up (about 0.5 percentage points for each additional $10 \mathrm{~cm}$ in height); (ii) having been successful in setting up a business in the past but no longer being involved in it or the business no longer being operational (about 0.5 percentage points for each additional $10 \mathrm{~cm}$ in height); (iii) having set up a business that is currently operational (approximately 1 percentage points for each additional $10 \mathrm{~cm}$ in height).

Our finding that height is an important predictor of involvement in entrepreneurship and the effect of height is stronger in magnitude than the effects of other well-known characteristics such as gender, health and university education have also significance from a policy standpoint. Thus, not reaching full height is translated to the significantly lower probability to be involved in entrepreneurship, while being an entrepreneur is associated with a wide range of positive outcomes such as higher earning and social status, greater levels of autonomy, better working conditions and higher work satisfaction. In turn, the literature repeatedly demonstrated that the main obstacles for attaining full potential height are the lack of investments into hygiene, sanitation, nutrition, health, education and positive environmental condition at earlier ages of child development (Bozzoli et al., 2009; Case \& Paxson, 2008b, 2011). Consequently, investments in the abovementioned areas are required to help individuals to reach their full height and increase the probability to be involved in entrepreneurship.

Several limitations of this study should be highlighted. First, relatively small country samples prevent us from conducting country-by-country analysis. Future studies may wish to take a more comparative approach in order to uncover possible country differences in the effects of height. Second, due to the limitations of secondary data analysis, we were not able to control for cognitive and non-cognitive abilities. Thus, future studies may wish to control for these measures, which correlate with height and consequently may explain the height premiums. Third, our data is cross sectional so we cannot identify cause and effect. Although reverse causality (e.g. from entrepreneurship to height) is unlikely, the influence of unobservable variables on both height and entrepreneurship could be plausible. Unfortunately, the lack of good instruments (e.g. the height of parents) prevents us from constructing an instrumental variable analysis for exploring the problem of unobservable variables.

\section{Conclusion}

To summarize, our findings allow us to theorize that the effect of height on becoming an entrepreneur can be considered to be a two-stage process. During the first stage, the individual decides whether to try to set up his or her own business. At this stage, the effect of height is stronger, indicating that relatively taller individuals are more likely to try to become 
entrepreneurs in comparison to shorter individuals. In other words, relatively shorter individuals, on average, are less likely to try to become entrepreneurs since entrepreneurship may require higher levels of abilities, intelligence, social skills and physical strength. During the second stage, after the decision to become an entrepreneur has already been taken, entrepreneurs could either attain success or failure in setting up and remaining active in their business. At this stage, although taller individuals are still more successful than their shorter counterparts, the effect of height is much weaker.

Availability of data and materials Data is available at www.ebrd.com. Code availability (software application or custom code) N/A.

Author contributions N.H. and A.A. developed the research idea, worked on the key sections of the paper and drafted the initial version of the manuscript. R.L. and A.A. were responsible for the methodology. R.L. was responsible for project administration. R.L. carried out the analysis. A.A. and R.L. interpreted findings. All the authors read and approved the final version of the manuscript.

\section{Declarations}

Competing interests The authors declare no competing interest.

Open Access This article is licensed under a Creative Commons Attribution 4.0 International License, which permits use, sharing, adaptation, distribution and reproduction in any medium or format, as long as you give appropriate credit to the original author(s) and the source, provide a link to the Creative Commons licence, and indicate if changes were made. The images or other third party material in this article are included in the article's Creative Commons licence, unless indicated otherwise in a credit line to the material. If material is not included in the article's Creative Commons licence and your intended use is not permitted by statutory regulation or exceeds the permitted use, you will need to obtain permission directly from the copyright holder. To view a copy of this licence, visit http://creativecommons.org/licenses/by/4.0/.

\section{References}

Ageev, A., Gratchev, M., \& Hisrich, R. (1995). Entrepreneurship in the Soviet Union and post-Socialist Russia. Small Business Economics, 7(5), 365-376. https://doi.org/10.1007/BF01302737.

Aidis, R., Estrin, S., \& Mickiewicza, T. (2008). Institutions and entrepreneurship development in Russia: A comparative perspective. Journal of Business Venturing, 23, 656-672. https://doi.org/10. 1016/j.jbusvent.2008.01.005.

Bargain, O., \& Zeidan, J. (2017). Stature, skills, and adult life outcomes: Evidence from Indonesia. The Journal of Development Studies, 53(6), 873-890. https://doi.org/10.1080/00220388.2016.1208173.

Becker, G. S. (1971). The economics of discrimination. University of Chicago Press.

Benz, M., \& Frey, B. S. (2008). Being independent is a great thing: Subjective evaluations of self-employment and hierarchy. Economica, 75, 362-383. https://doi.org/10.1111/j.1468-0335. 2007.00594.x.
Bozzoli, C., Deaton, A., \& Quintana-Domeque, C. (2009). Adult height and childhood disease. Demography, 46, 647-669. https://doi.org/ 10.1353/dem.0.0079.

Case, A., \& Paxson, C. (2008a). Stature and status: Height, ability, and labor market outcomes. Journal of Political Economy, 116, 499532. https://doi.org/10.1086/589524.

Case, A., \& Paxson, C. (2008b). Height, health and cognitive function at older ages. American Economic Review Papers and Proceedings, 98, 463-467. https://doi.org/10.1257/aer.98.2.463.

Case, A., \& Paxson, C. (2011). The long reach of childhood health and circumstance: Evidence from the Whitehall II study. Economic Journal, 121, 183-204. https://doi.org/10.1111/j.1468-0297.2011. 02447.x.

Cinnirella, F., \& Winter, J. (2009). Size matters! Body height and labor market discrimination: A cross-European analysis. CESifo Working Paper Series 2733. Munich: CESifo Group. Available at SSRN: https://ssrn.com/abstract=1443091

Djankov, S., Qian, Y., Roland, G., \& Zhuravskaya, E. (2006). Entrepreneurship in Brazil, China and Russia. In CEFIR Working Paper 66. Center for Economic and Financial Research.

European Bank for Reconstruction and Development (EBRD). (2016). Life in transition after the crisis. EBRD.

George, G., McGahan, A., \& Prabhu, J. (2012). Innovation for inclusive growth: Towards a theoretical framework and a research agenda. Journal of Management Studies, 49, 661-683. https://doi.org/10. 1111/j.1467-6486.2012.01048.x.

Grilo, I., \& Thurik, R. (2005). Latent and actual entrepreneurship in Europe and the US: Some recent developments. The International Entrepreneurship and Management Journal, 1, 441-459. https:// doi.org/10.1007/s11365-005-4772-9.

Gurov, G., \& Carstensen, F. (1983). Entrepreneurship in Imperial Russia and the Soviet Union. Princeton University Press.

Habibov, N., \& Cheung, A. (2017). Revisiting informal payments in 29 transitional countries: The scale and socio-economic correlates. Social Science \& Medicine, 178, 28-37. https://doi.org/10.1016/j. socscimed.2017.02.003.

Habibov, N., Afandi, E., \& Cheung, A. (2017a). What is the effect of university education on chances to be self-employed in transitional countries?: Instrumental variable analysis of cross-sectional sample of 29 nations. International Entrepreneurship and Management Journal, 13(2), 487-500. https://doi.org/10.1007/s11365-0160409-4.

Habibov, N., Cheung, A., \& Auchynnikava, A. (2017b). Does social trust increase willingness to pay taxes to improve public healthcare? Cross-sectional cross-country instrumental variable analysis. Social Science \& Medicine, 189, 25-34. https://doi.org/10.1016/j. socscimed.2017.07.023.

Habibov, N., Auchynnikava, A., Luo, R., \& Fan, L. (2020a). Influence of height on likelihood of employment, occupational sorting, and earnings in 27 post-communist countries. American Journal of Human Biology., 32(6), e23422. https://doi.org/10.1002/ajhb.23422.

Habibov, N., Luo, R., Auchynnikava, A., \& Fan, L. (2020b). Height and life satisfaction: Evidence from 27 nations. American Journal of Human Biology, 32(3), 1-13. https://doi.org/10.1002/ajhb.23351.

Hensley, W. E. (1993). Height as a measure of success in academe. Psychology: A Journal of Human Behavior, 30(1), 40-46.

Hübler, O. (2009). The Nonlinear Link between Height and Wages: An Empirical Investigation. Economics and Human Biology, 2009, 7 (2), 191-199. Available at SSRN: https://ssrn.com/abstract=943466

LaFave, D., \& Thomas, D. (2017). Height and cognition at work: Labor market in a low-income setting. Economics and Human Biology, 25, 52-64. https://doi.org/10.1016/j.ehb.2016.10.008.

Lindqvist, E. (2012). Height and leadership. The Review of Economics and Statistics, 94(4), 1191-1196. https://doi.org/10.1162/REST_a 00239. 
Long, S., \& Freese, J. (2014). Regression models for categorical dependent variables using Stata. Stata Press.

Magnusson, P. K., Rasmussen, F., \& Gyllensten, U. B. (2006). Height at age 18 years is a strong predictor of attained education later in life: Cohort study of over 950000 Swedish men. International Journal of Epidemiology, 35, 658-663. https://doi.org/10.1093/ije/dyl011.

Mavisakalyan, A. (2018). Do employers reward physical attractiveness in transition countries? Economics and Human Biology, 28, 38-52. https://doi.org/10.1016/j.ehb.2017.10.002.

McMillan, J., \& Christopher, W. (2002). The central role of entrepreneurs in transition economies. Journal of Economic Perspectives, 16, 153-170. https://doi.org/10.1257/089533002760278767.

Mussurov, A., \& Arabsheibani, R. (2015). Informal self-employment in Kazakhstan. IZA Journal of Labor \& Development, 4, 1-19. https:// doi.org/10.1186/s40175-015-0031-9.

Parker, S. C. (2009). The economics of entrepreneurship. Cambridge University Press. https://doi.org/10.1017/9781316756706.

Parker, S. C., \& Van Praag, M. (2010). Group status and entrepreneurship. Journal of Economics \& Management Strategy, 19(4), 919945. https://doi.org/10.1111/j.1530-9134.2010.00280.x.

Patzelt, H., \& Shepherd, D. A. (2011). Negative emotions of an entrepreneurial career: Self-employment and regulatory coping behaviors. Journal of Business Venturing, 26(2), 226-238. https://doi.org/10. 1016/j.jbusvent.2009.08.002.

Rietveld, C. A., Hessels, J., \& Van der Zwan, P. (2015). The stature of the self-employed and its relation with earnings and satisfaction. Economics \& Human Biology, 17, 59-74. https://doi.org/10.1016/ j.ehb.2015.02.001.
Sohn, K. (2015). The height premium in Indonesia. Economics and Human Biology, 16, 1-15. https://doi.org/10.1016/j.ehb.2013.12. 011.

Stulp, G., Buunk, A. P., Verhulst, S., \& Pollet, T. V. (2013). Tall claims? Sense and nonsense about the importance of height of US presidents. The Leadership Quarterly, 24(1), 159-171. https://doi.org/ 10.1016/j.leaqua.2012.09.002.

Stulp, G., Buunk, A. P., Verhulst, S., \& Pollet, T. V. (2015). Human height is positively related to interpersonal dominance in dyadic interactions. PLoS One, 10(2), e0117-e0860. https://doi.org/10. 1371/journal.pone. 0117860 .

Thomas, D., \& Strauss, J. (1997). Health and wages: Evidence on men and women in urban Brazil. Journal of Econometrics, 77(1), 159 185. https://doi.org/10.1016/S0304-4076(96)01811-8.

Vogl, T. (2014). Height, skills, and labor market outcomes in Mexico. Journal of Development Economics, 107, 84-96. https://doi.org/10. 1016/j.jdeveco.2013.11.007.

Welter, F. (2012). All you need is trust? A critical review of the trust and entrepreneurship literature. International Small Business Journal, 30(3), 193-212. https://doi.org/10.1177/0266242612439588.

Young, T. J., \& French, L. A. (1996). Height and perceived competence of US presidents. Perceptual and Motor Skills, 82(3), 1002-1002. https://doi.org/10.1177/003151259608200301.

Zebrowitz, L. A. (1994). Facial maturity and political prospects: Persuasive, culpable, and powerful faces. In R. C. Schank \& E. Langer (Eds.), Beliefs, reasoning, and decision making (pp. 315 346). Psychology Press. 